\title{
Archael Community Dynamics in Enriched Coffee Processing Wastes for Anaerobic Digestion
}

\author{
Sugitha Thankappan*, Nandha Kumar Belliraj and P. Paneerselvam \\ Department of Agricultural Microbiology, Tamil Nadu Agricultural University, \\ Coimbatore 641 003, India \\ Department of Natural Resource Management, Athiyaman College of Agriculture, \\ Hosur, India \\ National Rice Research Institute, Cuttack, Orissa, India \\ *Corresponding author
}

\section{A B S T R A C T}

\section{Keywords \\ Coffee pulp waste, Coffee processing waste water, \\ Microbial biomass, \\ $\mathrm{C} / \mathrm{N}$ ratio, \\ Anaerobes, \\ Temporal change, \\ Methane \\ Article Info \\ Accepted: \\ 10 September 2019 \\ Available Online: \\ 10 October 2019}

\section{Introduction}

Coffee is one of the popular beverages consumed throughout the world. The area under coffee cultivation has been increasing continuously due to its increased consumption. This lead to the accumulation of large quantities of coffee processing wastes every year in coffee plantations and curing works in

\begin{abstract}
The magnitude and diversity of the microbial population associated with coffee processing wastes viz., coffee pulp waste and coffee processing waste water was assessed. The anaerobic diversity was studied by an enrichment culture technique. The high $\mathrm{C} / \mathrm{N}$ ratio of coffee pulp waste promoted more microbial diversity than coffee processing waste water. The distribution pattern of diversified groups revealed an order of bacteria $>$ yeast $>$ fungi in coffee pulp waste and bacteria > fungi $>$ yeast in coffee processing waste water. Moreover, anaerobic population showed a significant positive correlation with the total microbial biomass in the enrichment culture throughout the enrichment process. With steady and maximum biogas production on $30^{\text {th }}$ day the methanogens occupied $2.18 \%$ of the total anaerobic population, $0.4 \%$ of each cellulolyzers and tannin degraders, $0.3 \%$ of pectinolyzers and $0.53 \%$ of acid formers. The different morphotypes were identified as majority belonging to the genera Clostridium, Methanosarcina sp., Methanococcus, Methanothrix etc. These results further suggest a significant linkage between the microbial community dynamics and function in the enriched coffee processing wastes over time. This can be further exploited for commercial generation of energy by biomethantion process from coffee processing wastes.
\end{abstract}

the form of coffee husk (pericarp and mesocarp) and parchment husk (endocarp) during the preparation of bean for commercial purposes. Wet processing of coffee generates large quantity of solid wastes, the coffee pulp and highly polluting liquid waste. During the processing seasons, the coffee pulp accumulates, causing an odour and fly nuisance, while drainage from heaps of pulp 
can pollute nearby watercourses. The waste water emanating during coffee processing is rich in total suspended and dissolved solids containing pectin, proteins and sugars which are biodegradable in nature. The concentrations of these pollutants vary with the nature (one time use / recycling) of water used for processing of fruits (Shanmukhappa et al., 1998).

Utilization of coffee processing wastes is receiving attention from every quarter, chiefly because of the magnitude of waste accumulated during its processing. Coffee pulp waste is being successfully employed as a cattle feed, to produce bio-fertilizer and organic manure for its high protein, calcium and phosphorus contents (Farinet and Pommares, 1999). In adopting a rational approach for the use and management of coffee processing wastes, the anaerobic digestion hold vast potential. Biomethanation is a fascinating biological phenomenon studied extensively to provide low cost energy in the form of methane. Biotechnology includes the use of microorganisms in largescale technological processes and anaerobic microbial treatment of waste and waste water. The biological process involves making use of specialized microorganisms to perform the desired degradation (Mattiasson and Holst, 1991). The biopolymers like pectin, cellulose contribute to the organic carbon and nitrogen content which influences the size of microbial biomass. The variation in microbial community structures and its composition can be correlated with spatial and temporal changes in certain functions both under controlled laboratory conditions (Avrahami et al., 2003) and in the field. But the understanding about the relative abundances of anaerobic bacteria is very poor. From the standpoint of coffee processing waste disposal, digesting the waste in anaerobic condition appears to be a tangible approach. Hence the present investigation has been carried out to study the degree of different functional group of anaerobic microbes including archae for further exploitation for biofuel /electricity generation from coffee processing wastes.

\section{Materials and Methods}

\section{Sampling of coffee processing waste samples}

Coffee pulp waste (CPW) and coffee processing waste water (CPWW) were collected from the waste disposal sites of the coffee processing units located at Thandikudi, in Palani hills of Tamil Nadu (Fig. 3) during the time of pulping. Sampling was done at different points and was collected under aseptic condition. For isolation of anaerobic microorganisms the samples were collected in a pre reduced buffer containing $\mathrm{Na}_{2} \mathrm{CO}_{3}(0.1$ $\%), \mathrm{NaHCO}_{3}(0.5 \%)$, cysteine $\mathrm{HCl}(0.025 \%)$ and resazurin $(0.0001 \%)$ and maintained under $\mathrm{N}_{2}$ atmosphere. The basic physico-chemical and biological properties viz., $\mathrm{pH}$ and $\mathrm{EC}$ Jackson (1973), Total Organic Carbon Walkley and Black (1934), Total Nitrogen Jackson (1973)), Protein (Lowry et al., (1951) $\mathrm{C} / \mathrm{N}$ ratio etc of coffee processing wastewater and coffee pulp waste were analyzed. The coffee pulp waste and coffee processing waste water were subjected to microbial characterization by standard pour plate technique using respective media viz., Nutrient Agar for bacteria, Rose Bengal Agar for fungi and Yeast extract Malt agar for Yeast (Aneja, 1996).

\section{Enrichment of coffee processing wastes for anaerobic isolation}

The coffee processing waste and coffee processing waste water were mixed equally in a ratio of 1:1 for enrichment and incubated for 30 days at $25^{\circ} \mathrm{C}( \pm 2)$. Biogas production was monitored by water displacement method at 
every 5 days interval and the per cent methane was analyzed in a Gas chromatograph with thermal conductivity detector (TCD) having 'Porapak Q' column by setting the oven temperature at $80{ }^{\circ} \mathrm{C}$ to $100{ }^{\circ} \mathrm{C}$, injector temperature at $100{ }^{\circ} \mathrm{C}$ to $200{ }^{\circ} \mathrm{C}$, detector temperature at $120{ }^{\circ} \mathrm{C}$ and using nitrogen as carrier gas at a flow rate of $30 \mathrm{ml} \mathrm{min}^{-1}$.

When the biogas production was maximum, samples were drawn aseptically for quantification of different anaerobic groups.

\section{Microbial biomass $\mathbf{C}$ and $\mathbf{N}$ determination}

Microbial biomass carbon (Cmic) was determined by the method described by Vance et al., (1987). Cmic was calculated from [extractable carbon $/ 0.45$, where extractable carbon $=(\mathrm{C}$ extracted from fumigated sample $)$ - (C extracted from non-fumigated sample). Microbial biomass $\mathrm{N}$ (Nmic) was estimated as (extractable nitrogen) $/ 0.54$, where extractable nitrogen $=($ total $\mathrm{N}$ extracted from fumigated sample) - (total $\mathrm{N}$ extracted from nonfumigated sample). Total protein content was estimated by Lowry's method (Lowry et al., (1951)].

\section{Isolation and enumeration of different functional anaerobic groups from enriched coffee processing wastes}

The total anaerobes, cellulolytic, pectinolytic, Tannin degrading anerobes, acid formers and methanogens were enumerated using Hungate's roll tube method (Hungate, 1969). For cellulolytic and pectinolytic anaerobes, cellulose $(1 \%)$ and pectin (1\%) were used instead of glucose, maltose and cellobiose in modified Hungate's medium (Ramasamy et al., 1992). For isolation of tannin degrading anaerobes, Rum 10 medium (Latham et al., 1978) containing tannic acid at a concentration of $1 \mathrm{~g}^{-1}$ was used.
The isolation media with respect to the organism to be isolated was reduced and sterilized, cooled and kept at $40^{\circ} \mathrm{C}$ in a water bath under $\mathrm{N}_{2}$ environment. The enriched samples were clarified by centrifugation at $20,000 \mathrm{x}$ g for $20 \mathrm{~min}$ at $4^{\circ} \mathrm{C}$ and one $\mathrm{ml}$ of the sample and five $\mathrm{ml}$ of the medium were added separately to the presterilized test tube containing $\mathrm{N}_{2}$ gassing canola and sterile rubber cork was introduced with simultaneous withdrawal of gassing canola. The content was gently mixed by tilting and rolled on a towel soaked in chill water in order to solidify the agar. The roll tubes were incubated at $35 \pm$ $2^{0} \mathrm{C}$ for 10 to 25 days and observed for growth of anaerobic microorganisms.

Individual colonies that showed clearing zone due to hydrolysis of cellulose and pectin in the roll tubes were transferred to the vials containing modified Hungate's mineral medium (Ramasamy et al., 1992) with 1 per cent cellulose, 0.1 per cent cellobiose and one per cent pectin as substrates.

\section{Quantification and isolation of Archae group}

Methanogens belonging to archae group were isolated and enumerated from the coffee processing waste enrichment using the medium defined by Mah et al., (1978) by roll tube technique. The roll tubes were incubated at $35 \pm 2{ }^{\circ} \mathrm{C}$ for 10 to 25 days and observed for the appearance of fluorescent colonies under UV lamp.

\section{Characterization of the anaerobic isolates}

The colony characteristics, cell morphology, biochemical characters viz., growth on different carbon substrates and utilization of different Carbon sources (Cato et al., 1986) of the purified strains were studied and characterized according to Hippe et al., 1992. 


\section{Results and Discussion}

\section{Characterization of coffee processing wastes}

The coffee pulp waste was subjected to various physico-chemical and biochemical analysis. It was acidic in $\mathrm{pH}$ (6.01) with EC of $0.78 \mathrm{dSm}^{-1}$ and registered maximum level of $\mathrm{N}, \mathrm{P}$ and $\mathrm{K}$ content of $1.54,0.41$ and 0.72 per cent respectively. The organic carbon content was 32.25 per cent and other proximate constituents were 5.85 per cent protein, 7.56 per cent cellulose, 5.65 per cent pectin, 6.12 per cent hemicellulose, 4.50 per cent total soluble sugars, 0.80 per cent reducing sugars, 4.50 per cent lignin and 6.4 per cent tannins (Table 1). The $\mathrm{C} / \mathrm{N}$ ratio is $21: 1$. Similar results were reported by Jeyarama et al., (1996) and Korikanthimath and Hosmani (1999) that the coffee pulp contains 6.5 per cent pectin, 2 per cent non reducing sugars and 10.1 per cent protein. This is in accordance with the findings of Pondey and Soccol (1998), Maheswari (2001) and Rajalakshmi (2006).

Coffee processing waste water (CPWW) was dark brown in colour exhibiting a phenolic odour with a $\mathrm{pH}$ of 3.93 and $\mathrm{EC}$ of 1.16 $\mathrm{dSm}^{-1}$. The acidic $\mathrm{pH}$ is due to the fermentation of sugars present in the coffee processing waste water in the presence of yeast to alcohol and $\mathrm{CO}_{2}$. Then the alcohol is quickly converted in to vinegar (or) acetic acid in the fermented pulping water resulting in lower $\mathrm{pH}$ (Calvert, 1997). The EC value is in accordance with the findings of De Matos et al., (2001). They reported that the EC ranged from 0.932 to $1.069 \mathrm{dSm}^{-1}$ in the waste water from the coffee fruits processing.

The total dissolved solids (TDS) and total suspended solids (TSS) were 1060 to 1320 and 2420 to $2810 \mathrm{mg} \mathrm{l}^{-1}$ respectively. The total solid content (TS) was 3480 to $4190 \mathrm{mg} \mathrm{l}^{-1}$.
The higher amount of suspended solids present in coffee processing waste water might be due to the presence of pectin, protein and sugars which are biodegradable in nature. The concentrations of these organics vary with quantity of water used for processing of fruits. This is in conformation with the reports of Shanmukhappa et al., (1998). The BOD of the CPWW ranged from 3800 to $4920 \mathrm{mg} \mathrm{l}^{-1}$, which might be due to the presence of high amount of organic substances. This concentration is due to the double wash of coffee fruits during processing. Still higher BOD was obtained by Shanmukhappa et al., (1998) who reported a BOD concentration of $10,000-12,000 \mathrm{mg}^{-1}$ in coffee processing waste water. The high level of COD concentration (7900 to $9620 \mathrm{mg} \mathrm{l}^{-1}$ ) in the coffee processing waste water could be attributed to the slowly degrading compounds present in the coffee processing waste water.

The total organic carbon content of the waste water was 0.51 per cent. The dissolved oxygen (DO) content of the waste water was very low with a value of 2.2 to $2.6 \mathrm{mg} \mathrm{l}^{-1}$. The BOD and COD were 3800 to 4920 and 7900 to $9620 \mathrm{mg}$ $1^{-1}$, respectively. The total nitrogen, phosphorus and potassium content of the waste water were recorded as 172.6, 7.2 and $44.2 \mathrm{mg} \mathrm{l}^{-1}$ respectively with a $\mathrm{C} / \mathrm{N}$ ratio of $3: 1$ (Table 1). These results are in line with the findings of De Matos et al., (2001)). They reported the nitrogen, phosphorous and potassium concentration of $185.6,6.5$ and 44.4 $\mathrm{mg} \mathrm{l}^{-1}$ respectively.

\section{Enumeration of total microbial flora from coffee processing wastes}

The native population of bacteria, fungi and yeast were maximum in the coffee pulp waste $\left(13.35 \times 10^{7}, 17.65 \times 10^{4}\right.$ and $31 \times 10^{4} \mathrm{CFU} \mathrm{g}^{-1}$ of coffee pulp waste respectively) compared to coffee processing waste water $\left(15.4 \times 10^{6}, 4.9\right.$ x $10^{4}$ and $7.0 \times 10^{2} \mathrm{CFU} \mathrm{ml}{ }^{-1}$ respectively). In 
general, the population of bacteria was recorded higher followed by fungi and yeast (Fig. 1). The results clearly indicate a rich diversity of microorganisms in the coffee processing wastes. Fermentation is a critical stage in wet processing of coffee. Coffee fermentation is attributed by a wide range of microorganisms like bacteria, fungi and Saccharomyces sp. The population of bacteria, fungi and yeast were recorded maximum in coffee pulp which might be due to the physico-chemical characteristics of coffee pulp waste which recorded a $\mathrm{pH}$ of 6.01 and EC of $0.78 \mathrm{dSm}^{-1}$ and more amount of biochemical constituents like pectin, sugars, protein etc., compared to coffee processing waste water. Sugars and proteins serve as carbon and nitrogen source for the growth of microorganisms.

The high $\mathrm{C} / \mathrm{N}$ ratio of coffee pulp also has profound impact on the microbial load. The presence of more organics in coffee pulp might be the reason for rich microbial diversity when compared to coffee processing waste water with very less $\mathrm{C} / \mathrm{N}$ ratio of $3: 1$.

Quantification and characterization of anaerobes and archae from coffee processing wastes enrichment

The biogas production and methane content was monitored at every 5 days interval and it was observed that maximum biogas (195.5 $\mathrm{ml}$ ) with methane content of $40 \%$ was produced between 25 to 30 days. A sudden decline in biogas generation was noticed afterwards. In general, the biogas production and methane content increased with the advancement of enrichment till 30 days. The total protein content of the enrichment was $134.0 \mu \mathrm{g} \mathrm{ml}^{-1}$ on 30th day and the microbial population was also enumerated. This indicates the presence of more diverse anaerobic bacteria with different biocatalytic ability. The total microbial biomass and total microbial Nitrogen also showed an increasing trend till $30^{\text {th }}$ day and dropped down after 30 days (Table 2).

The population of total anaerobes $\left(32.0 \times 10^{5}\right.$ CFU ml $\left.{ }^{-1}\right)$, cellulolyzers $\left(13.0 \times 10^{3} \mathrm{CFU}\right.$ $\left.\mathrm{ml}^{-1}\right)$, pectinolyzers $\left(11.0 \times 10^{3} \mathrm{CFU} \mathrm{ml} \mathrm{m}^{-1}\right)$,

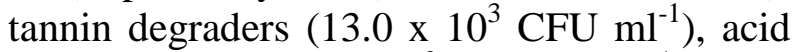
formers $\left(17.0 \mathrm{x} \quad 10^{3} \mathrm{CFU} \quad \mathrm{ml}^{-1}\right)$ and methanogens $\left(7.0 \times 10^{4} \mathrm{CFU} \mathrm{\textrm {ml } ^ { - 1 }}\right)$ were recorded. The proportion of each group was worked out and expressed in terms of percentage. On $30^{\text {th }}$ day the methanogens occupied $2.18 \%$ of the total anaerobic population, $0.4 \%$ of each cellulolyzers and tannin degraders, $0.3 \%$ of pectinolyzers and $0.53 \%$ of acid formers. The results are given in Figure 2. A significant positive correlation was observed microbial biomass and microbial nitrogen content. As microbial biomass increases the total microbial nitrogen also increased and vice versa. The total microbial nitrogen indirectly represents protein content. Several studies also reported that the changes in overall community structures and composition can be correlated with the changes in protein or enzymes under controlled condition. More over the temporal variability of microbial biomass dynamics is complex in enrichment culture and it is very clear that microbial succession well operates under this condition. After 30 days the bioconversion process gradually reduced due to less activity of the enzyme complex system due to deprivation of nutrients.

The high $\mathrm{C}_{\text {mic }} / \mathrm{N}_{\text {mic }}$ ratio of 10.82 on $40^{\text {th }}$ day might be due to dead microbial cells. Enrichment cultures that contain methane as the sole carbon and energy source support the growth of bacteria belonging to several genera: Methylomonas, Methylococcus, Methylosinus. Some can grow only with methane, methanol or dimethyl ether as substrate and are unable to use sugars, organic acids or other alcohols. 
Table.1 Physico-chemical characteristics of coffee processing wastes

\begin{tabular}{|l|l|l|l|l|l|}
\hline Parameters & $\mathbf{p H}$ & $\begin{array}{l}\mathbf{E C} \\
\left(\mathbf{d S m}^{-\mathbf{1})}\right.\end{array}$ & $\begin{array}{l}\text { Organic } \\
\text { Carbon } \\
(\boldsymbol{\%})\end{array}$ & $\begin{array}{l}\text { Total } \\
\text { Nitrogen } \\
(\boldsymbol{\%})\end{array}$ & $\mathbf{C} / \mathbf{N}$ ratio \\
\hline CPW & 6.01 & 0.78 & 32.25 & 1.54 & $\mathbf{2 1 : 1}$ \\
\hline CPWW & $\mathbf{3 . 9 3}$ & $\mathbf{1 . 1 6}$ & $\mathbf{0 . 5 1}$ & $\mathbf{0 . 1 7}$ & $\mathbf{3 : 1}$ \\
\hline
\end{tabular}

Table.2 Total Microbial biomass and Nitrogen $(n=3$; mean $+/-$ SD) in coffee processing wastes enrichment

\begin{tabular}{|l|l|l|l|l|}
\hline Days & \multicolumn{1}{|c|}{$\mathbf{1 0}$} & \multicolumn{1}{c}{$\mathbf{2 0}$} & \multicolumn{1}{c|}{$\mathbf{3 0}$} & \multicolumn{1}{c|}{$\mathbf{4 0}$} \\
\hline $\mathbf{C}_{\text {mic }}$ & $196.9+/-4.0^{\mathrm{d}}$ & $294.8+/-4^{\mathrm{b}}$ & $351.2+/-2.2^{\mathrm{a}}$ & $\mathbf{2 9 1 . 6 + / - 4 . 1 ^ { \mathrm { c } }}$ \\
\hline $\mathbf{N}_{\text {mic }}$ & $20.1+/-4.5^{\mathrm{d}}$ & $28.0+/-4.2^{\mathrm{b}}$ & $32.7+/-2.3^{\mathrm{a}}$ & $\mathbf{2 6 . 9 3 + / - 2 . 5 ^ { \mathbf { c } }}$ \\
\hline $\mathbf{C}_{\text {mic }} / \mathbf{N}_{\text {mic }}$ & $\mathbf{9 . 8 1}$ & $\mathbf{1 0 . 5 2}$ & $\mathbf{1 0 . 7 4}$ & $\mathbf{1 0 . 8 2}$ \\
\hline
\end{tabular}

(Different letters in the same row indicate significant differences $(\mathrm{p}<0.05)$

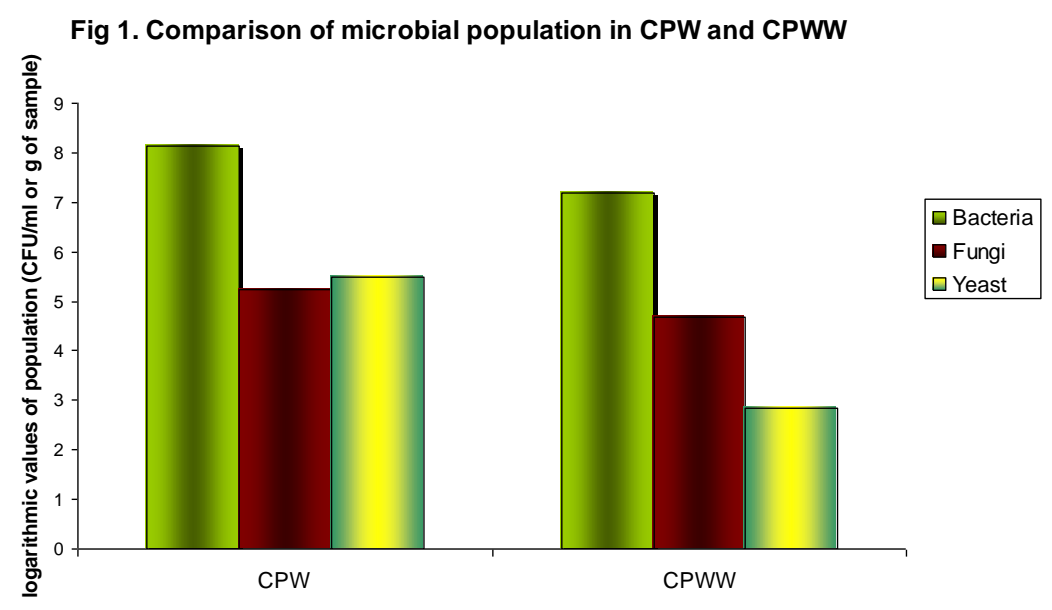

Fig 2.Proportion of different groups of anerobs vs total anerobes in coffee processing wastes

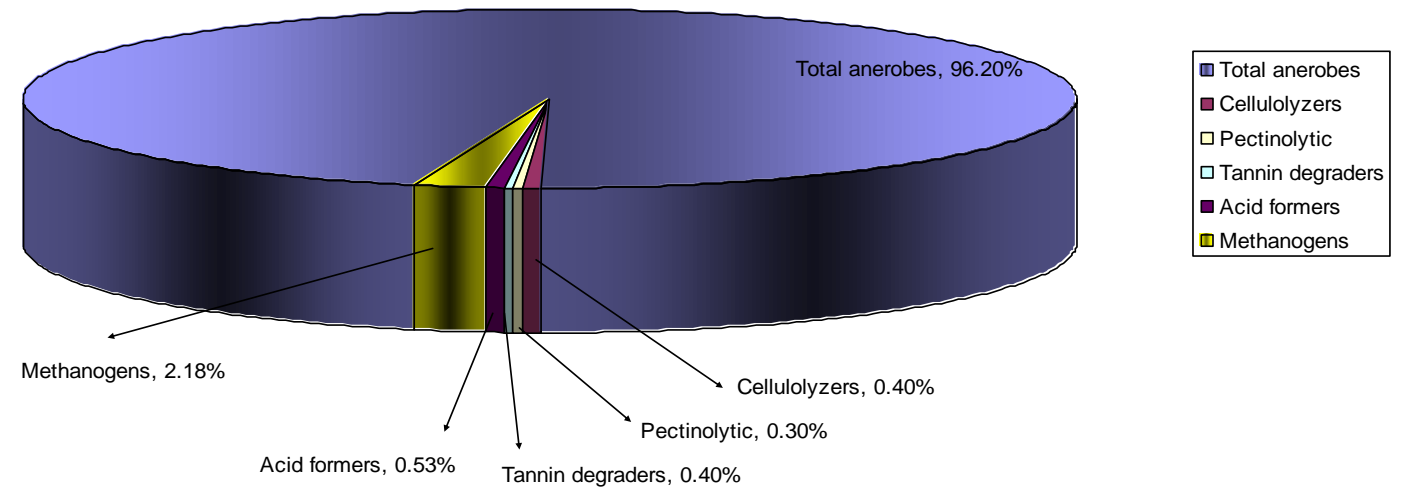


Fig.3 Geographical location representing the site of sample collection

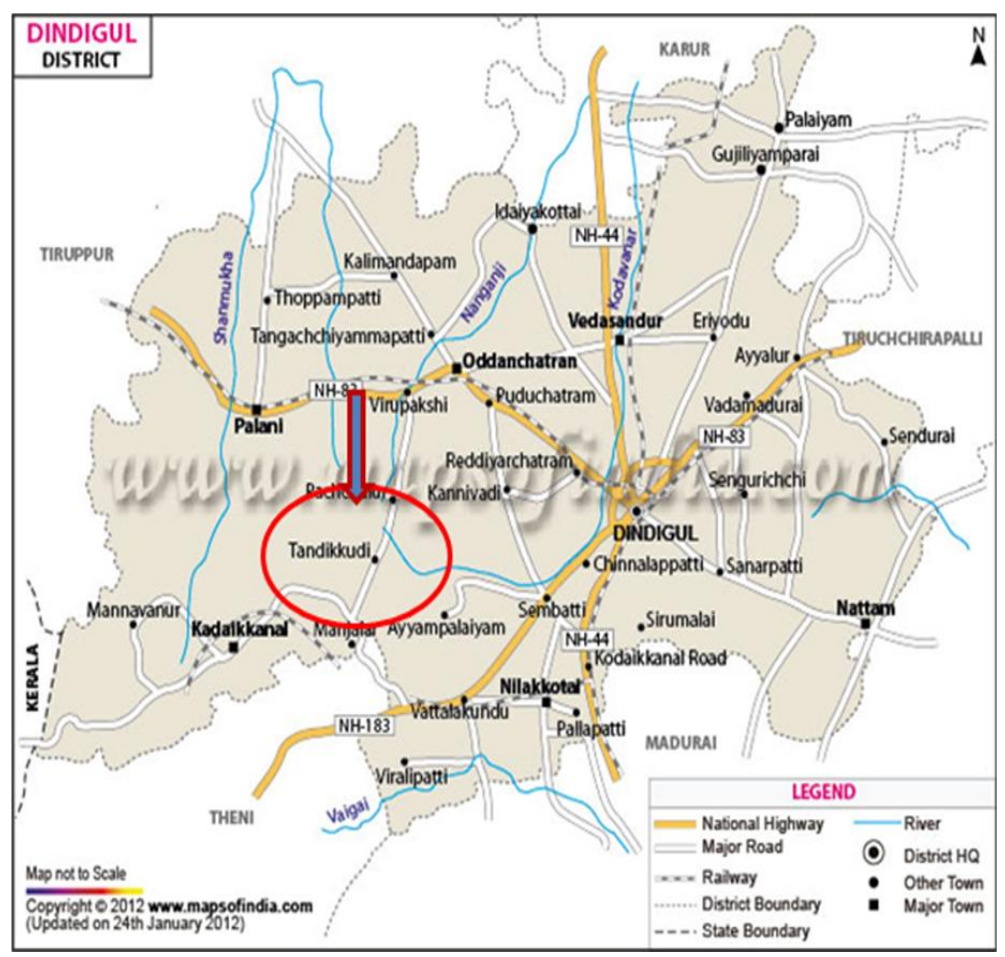

Biochemical characterization of the isolates showed that four were sporulating in nature and responded positive to gram reaction. Similar observation was made by Bredholt et al., (1995) and Nagamani (1996) who reported that sporulating cellulolytic bacteria are common than non sporulating cellulolyzers in both mesophilic and thermophilic environments. The isolates were able to use different sugars like glucose, fructose, sucrose and complex polysaccharides like cellobiose, cellulose, filter paper and pectin. The isolates TCW 4 and strain TCW 5 could utilize tannic acid also. Based on the biochemical properties, TCW 1, TCW 2, TCW 3 and TCW 5 were related to Clostridium sp. Nagamani (1996) also observed similar characteristics with the Clostridium sp. isolated from compost pit. Obi (1981) isolated Clostridium butyricum and Clostridium felsineium capable of degrading pectin. Tamaru and Doi (2001) characterized cellulosomal pectinase from
Clostridium thermocellum, C. cellulovorans, C. cellulolyticum. Jinn et al., (1988) isolated Clostridium thermocopriae from animal faeces, similar to the habitat of cowdung fed biogas digester.

Methanogens are the unsung heroes of the global carbon cycle at the bottom of the food chain having $\mathrm{CH}_{4}$ as a stoichiometric product of their metabolism (Sowers, 1995). The morphology and substrate diversity of the isolate from coffee processing wastes enrichment is characteristic of the genus Methanosarcina, Methanothrix and Methanococcus. The ability of the isolate to form clumps or aggregates during growth is also the typical way of Methanosarcina life style. Isolation of methanogens was done from roll tubes after identifying the fluorescent colonies. The fluorescence is characteristic of methanogens due to the presence of $\mathrm{F}_{420}$, during active metabolism, 80 per cent of $\mathrm{F}_{420}$ exists in the oxidised form. 
$\mathrm{F}_{420}$ is cell bound and therefore its fluorescence is confined to the colony. There was ample $F_{420}$ to permit direct visual observation of the methanogenic colonies when they were exposed to long wave UV light (Edwards and McBride, 1975). The enumeration revealed the formation of $7.0 \mathrm{x}$ $10^{4}$ colony forming units in enriched coffee processing wastes Methanogenic communities have been described in habitats such as rumen (Wright et al., 2004) and termite guts (Ohkuma et al., 1999). Presence of methanogens in coffee processing wastes is therefore the first report apart from wetland soil, rumen and termite guts.

The colonies of Methanosarcina sp. were circular with entire margin, convex, creamy and exhibited fluorescence. Individual cells were irregular in shape and aggregated in masses of a few to several units. Purification of the isolate was done by acetate enrichment using antibiotics which inhibit eubacterial cell wall synthesis (Hilpert et al., 1981). Mah and Smith (1981) successfully employed antibiotics to reduce the eubacterial growth during isolation of methanogens.

Similarly we found pronounced genetic diversity of anaerobic and archael communities in the enrichment culture. A certain degree of succession occurs in the anaerobic communities of the coffee processing wastes enrichment. This study illustrates the significances of microbial community dynamics and function over time in a bioconversion process. It also opened a wide vista of potential heroes of anaerobes and archae for biodegradation of important bio- polymers like cellulose and recalcitrant pectin and tannin with potential generation of energy. This study clearly showed that coffee processing wastes is a potential wealth in terms of anaerobic fermentation. A future investigation is required to develop a microbial consortium using the elite strains for biocatalytic activity and optimization of bioprocess parameters in bioreactors before commercial exploitation.

In conclusion, coffee waste water is a environmental issue and addressing safe disposal of coffee wastes is gaining momentum. In this context, studies on the microbial dynamics of coffee processing wastes and exploitation of culturable and unculturables will help to develop an integrated strategy for bioconversion of coffee wastes in to value added commodities.

\section{Acknowledgement}

The authors are thankful to the Coffee board, Govt. of India, for financing this research project on "Bioprocessing technologies for the value addition of coffee wastes".

\section{References}

Aneja, K.R., 1996. Experiments in Microbiology, Plant Pathology Tissue Culture and Mushroom cultivation. $2^{\text {nd }}$ Edition. Wishwa Prakashan, New Delhi.

Avrahami, S., W. Liesack and R. Conrad, 2003. Effects of temperature and fertililizer on activity and community structure of soil ammonia oxidizers. Environ. MIcrobiol., 5: 691-705.

Bredholt, S., I.M. Mathrani and B.K. Ahring, 1995. Extremely thermophilic celluolytic anaerobes from Icelandic hotsprings. Anton. Van Leeuwen, 68: 263-271.

Calvert, C.K., 1997. The treatment of coffee processing waste waters: The biogas option a review and preliminary report. Coffee Industry Corporation Ltd, Coffee Research Institute, Papua New Guinea.

Cato, E.P., W.L. George and S.M. Finegold, 1986. The Genus Clostridium. In: Bergey's Manual of Systematic Bacteriology, Sneath, H.A., N.S. Mair, M.E. Sharpe and J.G. Holt (Eds.). Vol. 2, The Williams and Wilkins Co., Baltimore, pp: 1141-1200.

De Matos, A.T., P.A. Lo Monaco, A.B. Pinto, R. Fia and D.C. Fukunaga, 2001. Pollutant 
potential of wastewater of the coffee fruits processing. Water Res., 33: 2441-2447.

Edwards, T. and B.C. McBride, 1975. New method for the isolation and identification of methanogenic bacteria. Applied Microbiol., 29: 540-545.

Farinet, J.L. and P. Pommares, 1999. Anaerobic digestion of coffee pulp. A pilot scale study in Mexico. Proceedings of the $2^{\text {nd }}$ International Symposium on Anaerobic Digestion of Solid Waste, Volume 2, June 15-18, 1999, Barcelona, Spain, pp: 129132.

Hilpert, R., J. Winter, W. Hammes and O. Kandler, 1981. The sensitivity of Archae bacteria to antibiotics. Zentralblatt für Bakteriologie Mikrobiologie und Hygiene: I. Abt. Originale C: Allgemeine, Angewandte und Okologische Mikrobiol., 2: 11-20.

Hippe, H., J.R. Andreeson and G. Gottschalk, 1992. The Genus Clostridium-Non Medical. In: The Prokaryotes: A Handbook on the Biology of Bacteria: Ecophysiology, Isolation, Identification, Applications, Balows, A., H.G. Truper, M. Dworkin, W. Harder and K.H. Schleifer (Eds.). Vol. 1, Springer-Verlag, New York, pp: 18001866.

Hungate, R.E., 1969. A roll tube method for cultivation of strict anaerobes. Methods in Microbiol., 3B: 117-132.

Jackson, M.L., 1973. Soil Chemical Analysis. Prentice Hall of India Private Limited, New Delhi., pp. 498.

Jeyarama, K., C.S. Naik, R.P.A. Alwar and R. Naidu, 1996. Biodegradable organic matters as potential source of coffee nutrition in coffee plantation in India. Indian Coffee, 60: 3-8.

Jinn, F., K. Yamasato and K. Toda, 1988. Clostridium thermocopriae sp. nov., a cellulolytic thermophile from animal feces, compost, soil and a hot spring in Japan. Int. J. Syst. Evolut. Microbiol., 38: 279-281.

Korikanthimath, V.S. and M.M. Hosmani, 1999. Organic recycling of coffee pulp in coffee based cropping systems. Indian Coffee, 64: 4-6.

Latham, M.J., B.E. Brooker, G.I. Pettipher and P.J. Harris, 1978. Adhesion of Bacteroides succinogens in pure culture and in the presence of Ruminococcus flavefaciens to cell walls in leaves of perennial ryegrass .Applied Environ. Microbiol., 35: 11661173.

Lowry, O.H., N.J. Rose Brought, A.J. Larr and R.J. Randall, 1951. Protein measurement with folin-phenol reagent. J. .Biol.and Chem., 193: 265-275.

Mah, R.A. and M.R. Smith, 1981. The Methanogenic Bacteria. In: The Prokaryotes, Starr, M.P., H. Stolp, H.G. Truper, A. Balows and H.B. Schlegel (Eds.). Springer - Verlag, New York.

Mah, R.A., M.R. Smith and L. Baresi, 1978. Studies on an acetate-fermentation strain of Methanosarcina. Applied Environ. Microbiol., 35: 1174-1184.

Maheswari, M., 2001. Value added product from coffee pulp waste. Ph.D. Thesis, Tamil Nadu Agric University, Coimbatore.

Mattiasson, B. and O. Holst, 1991. Extractive Bioconversions. Marcel Dekker, New York, ISBN: 9780824782726, Pages: 328.

Nagamani, B., 1996. Cellulase complex of thermophilic Clostridia purified from three ecosystems. Ph.D. Thesis, Tamil Nadu Agricultural University, Coimbatore, Tamil Nadu, India.

Ohkuma, M., S. Noda and T. Kudo, 1999. Phylogenetic relationships of symbiotic methanogens in diverse termites. FEMS Microbiol. Lett., 171: 147-153.

Pondey, A. and C.R Soccol, 1998. Bioconversion of biomass: A case study of lignocellulosics bioconversions in solid state fermentation. Brazil. Arch. Biol. Technol., 4: 379-390.

Rajalakshmi, P., 2006. Bioconversion of coffee pulp waste into value added manure. M.Sc. Thesis, Tamil Nadu Agricultural University, Coimbatore, Tamil Nadu, India.

Ramasamy, K., G. Kalaichelvan and B. Nagamani, 1992. Working with anaerobes: Methanogens-A laboratory manual, fermentation laboratory. Tamil Nadu Agricultural University, Coimbatore.

Shanmukhappa, D.R., R.P. Ananda Alwar and C.S. Srinivasan, 1998. Water pollution by coffee processing units and its abatement. Indian Coffee, 59: 3-9. 
Sowers, K.R., 1995. Methanogenic Archae: An Overview. In: Archae: A Laboratory Manual, Robb, F.T., A.R. Place, K.R. Sowers, H.J. Schreier, S. DasSarma and E.M. Fleischmann (Eds.). Vol. 2, CSHL Press, Plainview, pp: 3-13.

Tamaru, Y. and R.H. Doi, 2001. Pectate lyase A, an enzymatic subunit of the Clostridium cellulovorans cellulosome. Proc. National Acad. Sci., 98: 4125-4129.

Vance, E.D., P.C. Brookes and D.S. Jenkinson, 1987. An extraction method for measuring soil microbial biomass C. Soil Biol \&
Biochem., 19:703-707.

Walkley, A. and I.A. Black, 1934. An examination of the method for determining soil organic matter and proposed modification of the chromic acid titration method. Soil Science, 37: 29-38.

Wright, A.D.G., A.J. Williams, B.Winder, C.T. Christophersen, S.L. Rodgers and K.D. Smith, 2004. Molecular diversity of rumen methanogens from sheep in Western Australia. Appl. Environ. Microbiol., Appl. Environ. Microbiol., Pp. 1263-1270

\section{How to cite this article:}

Sugitha Thankappan, Nandha Kumar Belliraj and Paneerselvam, P. 2019. Archael Community Dynamics in Enriched Coffee Processing Wastes for Anaerobic Digestion. Int.J.Curr.Microbiol.App.Sci. 8(10): 1042-1051. doi: https://doi.org/10.20546/ijcmas.2019.810.122 